\title{
Palygorskite Supplementation Improves Growth Performance, Oxidative Status, and Intestinal Barrier Function in Cherry Valley Ducks
}

\author{
Yuyu Wang, Baozhe Wang, Qiang Liu, Chengrui Fan, Jiaying Li, Yanmin Zhou and Su Zhuang \\ College of Animal Science and Technology, Nanjing Agricultural University, Nanjing 210095, China
}

\begin{abstract}
The effects of dietary palygorskite (Pal) supplementation on growth performance, oxidative status, and intestinal barrier function in ducks were investigated. In total, 720 one-day-old Cherry Valley ducks were categorized into 4 treatments comprising 6 replicates with 30 ducks each. Ducks were fed a basal diet supplemented with $0,5,10$, or 20 $\mathrm{g} / \mathrm{kg}$ Pal for 42 days. Twenty-four ducks ( 1 male/replicate) were slaughtered at 14 and 42 days and samples were collected for analysis. Pal supplementation quadratically increased weight gain and linearly and quadratically increased feed intake $(P<0.05)$ during the starter period. Pal enhanced serum glutathione peroxidase activity (GSHPx) at 14 (linear and quadratic, $P<0.05$ ) and 42 days (linear, $P<0.001$ ), and lowered serum malondialdehyde (MDA) content at 14 and 42 days (quadratic, $P<0.05$ ). It enhanced 42-day liver superoxide dismutase activity (linear, $P=$ 0.003 ) and GSH-Px activity at 14 (quadratic, $P=0.044$ ) and 42 days (linear and quadratic, $P<0.001$ ), but decreased 14-day liver MDA content (quadratic, $P=0.003$ ). Pal reduced 42-day serum diamine oxidase activity (linear and quadratic, $P<0.05$ ) and serum endotoxin content at 14 (linear and quadratic, $P<0.05$ ) and 42 days (quadratic, $P=$ 0.017). It linearly and quadratically increased jejunal mucosal immunoglobulin (Ig) $\mathrm{M}$ at 42 days and $\operatorname{IgG}$ at 14 and 42 days, and 42 -day ileal mucosal $\operatorname{IgG}$ and secretory $\operatorname{IgA}(P<0.05)$. Ileal mucosal $\operatorname{IgM}$ content was quadratically increased at 14 and 42 days $(P<0.05)$ by Pal. Moreover, Pal enhanced the mRNA expression of 14-day occludin in the jejunal mucosa (quadratic, $P=0.033$ ) and that of 42-day zonula occludens-1 in the ileal mucosa (linear, $P=$ 0.027). Thus, dietary Pal supplementation exerts beneficial effects through improving growth performance, antioxidant capacity, and intestinal barrier function of ducks.
\end{abstract}

Key words: barrier function, Cherry Valley ducks, growth performance, oxidative status, palygorskite

J. Poult. Sci., 56: 186-194, 2019

\section{Introduction}

Palygorskite (Pal) is a natural magnesium aluminum silicate clay mineral comprised of ribbons of a 2:1 phyllosilicate unit $\left(\mathrm{Si}_{8} \mathrm{Mg}_{8} \mathrm{O}_{20}(\mathrm{OH})_{2} \cdot 4 \mathrm{H}_{2} \mathrm{O}\right)$ (Galán, 1996; Murray, 2000). Owing to its unique physicochemical properties, including small partical size and a fibrous structure with micropores and channels (Galán, 1996; Zhou, 2011; Xu et al., 2012), Pal has a high absorption capacity, colloidal and swelling capacity, optimal rheological behavior, and high water dispersibility (Ghadiri et al., 2015). Pal is applicable in various industries as well as in animal nutrition (Murray, 2000; Chalvatzi et al., 2014).

Recently, Pal has been gradually adopted in animal pro-

Received: March 28, 2018, Accepted: September 3, 2018

Released Online Advance Publication: November 25, 2018

Correspondence: Dr. Su Zhuang, College of Animal Science and Technology, Nanjing Agricultural University, Nanjing 210095, China. (E-mail: zhuangsu@njau.edu.cn), and Dr. Qiang Liu, College of Animal Science and Technology, Nanjing Agricultural University, Nanjing 210095, China. (E-mail: Liuayang@njau.edu.cn) duction either as a feed pellet binder or as animal feed supplement because of its aforementioned characteristics (Murray, 2000; Yan et al., 2016). Dietary Pal supplementation has been reported to enhance feed pellet quality and to increase the average daily gain in broilers (Zhang et al., 2017). It has been suggested that $\mathrm{Pal}$ addition improves immunity oxidative status, intestinal integrity, and digestive function of broilers (Chen et al., 2016a, b). Supplementation of dietary $\mathrm{Pal}$ in weaned piglets reportedly improves growth performance while reduces the diarrhea rate, thus improving intestinal integrity (Zhang et al., 2013; Lv et al., 2015). In addition, Pal supplementation improves laying hen performance and egg quality (Chalvatzi et al., 2014), and the milk yield of lactating Holstein cows and milk quality of cows and ewes (Bampidis et al., 2014; Kotsampais et al., 2017).

Considering the antioxidant effects and protective roles of dietary $\mathrm{Pal}$ supplementation in those animal models, we reasoned that Pal supplementation might benefit ducks as well. Therefore, this study aimed to determine the effects of Pal supplementation on growth performance, antioxidant capacity, and intestinal barrier function of Cherry Valley 
ducks.

\section{Materials and Methods}

\section{Pal}

Pal was obtained from Jiangsu Sinitic Biotech Co., Ltd. (Xuyi, Jiangsu, China). The main chemical constituents of Pal as determined with a Minipal 4 X-ray fluorescence spectrometer (PANanalytical Co., Almelo, Netherlands) were: $\mathrm{SiO}_{2}, 56.32 \% ; \mathrm{Al}_{2} \mathrm{O}_{3}, 10.25 \% ; \mathrm{MgO}, 13.32 \%$; $\mathrm{CaO}, 10.14$ $\% ; \mathrm{K}_{2} \mathrm{O}, 1.15 \% ; \mathrm{Na}_{2} \mathrm{O}, 0.77 \%$ and $\mathrm{Fe}_{2} \mathrm{O}_{3}, 6.02 \%$.

\section{Animals, Diets, and Experimental Design}

All procedures were approved by Nanjing Agricultural University Institutional Animal Care and Use Committee. For the trial, 720 one-day-old Cherry Valley ducks (obtained from a commercial hatchery) having a similar initial body weight $(50.00 \pm 0.20 \mathrm{~g})$ were randomly allocated to 4 dietary treatments. Each treatment consisted of 6 replicates with 30 ducks ( 15 males and 15 females per replicate). The ducks were fed with a basal diet supplemented with 0 (control group), 5, 10, or $20 \mathrm{~g} / \mathrm{kg}$ Pal for 42 days. The basal diet was formulated according to Nutrient Requirements of MeatType Duck of China (NY/T 2122-2012). The composition and nutrient content of the basal diet are listed in Table 1. Ducks were allowed ad libitum access to pellet feed and water on a plastic slatted floor in a temperature-controlled room with continuous lighting. The temperature was maintained at $32-33^{\circ} \mathrm{C}$ for the first 3 days and was then gradually decreased by $2-3^{\circ} \mathrm{C}$ per week to a final temperature of $26^{\circ} \mathrm{C}$. The experimental period consisted of a starter period ( 1 to 14 days) and a grower period (15 to 42 days). At 14 and 42 days, ducks were weighed in replicate after feed deprivation for $12 \mathrm{~h}$, and feed intake was recorded in replicate to calculate average daily feed intake (ADFI), average daily gain (ADG), and feed/gain ratio (F/G).

\section{Sample Collection}

At 14 and 42 days, 24 randomly selected male ducks (1 duck per replicate) were weighed after feed deprivation for $12 \mathrm{~h}$. Blood samples $(5 \mathrm{~mL})$ taken from the wing vein were centrifuged at $4450 \times g$ for $15 \mathrm{~min}$ at $4^{\circ} \mathrm{C}$ to obtain serum, which was stored at $-28^{\circ} \mathrm{C}$ until analysis. After blood collection, the ducks were immediately euthanized by cervical dislocation and necropsied. The liver samples were quickly excised, frozen in liquid nitrogen, and stored at $-80^{\circ} \mathrm{C}$ for antioxidant capacity assay. The bursa of Fabricius, thymus,

Table 1. Composition and nutrient level of basal diet (g/kg, as fed basis)

\begin{tabular}{|c|c|c|}
\hline Item & 1-14 days & $15-42$ days \\
\hline \multicolumn{3}{|l|}{ Ingredient } \\
\hline Corn & 500 & 520 \\
\hline Wheat & 30 & 100 \\
\hline Wheat midding & 110 & 80 \\
\hline Cottonseed meal & 50 & 60 \\
\hline Soybean meal & 80 & 50 \\
\hline Corn gluten meal & 100 & 70 \\
\hline Meat and born meal & 30 & 30 \\
\hline Rice bran & 65 & 51 \\
\hline L-Lysine & 1.5 & 2 \\
\hline DL-Methionine & 1.5 & 2 \\
\hline Limestone & 14 & 12 \\
\hline Dicalcium phosphate & 5 & 10 \\
\hline Sodium chloride & 3 & 3 \\
\hline Premix $^{\mathrm{a}}$ & 10 & 10 \\
\hline \multicolumn{3}{|l|}{ Calculated nutrient level } \\
\hline Apparent metabolizable energy $(\mathrm{MJ} / \mathrm{kg})$ & 12.13 & 12.34 \\
\hline Crude protein & 193.8 & 171.9 \\
\hline Calcium & 9.5 & 10.0 \\
\hline Available phosphorus & 4.0 & 3.9 \\
\hline Lysine & 11.0 & 7.8 \\
\hline Methionine & 4.5 & 4.3 \\
\hline Methionine + cystein & 7.7 & 7.1 \\
\hline \multicolumn{3}{|l|}{ Analyzed nutrient composition } \\
\hline Crude protein & 195.9 & 175.0 \\
\hline Crude ash & 62.1 & 77.0 \\
\hline Calcium & 9.4 & 9.7 \\
\hline Total phosphorus & 11.3 & 11.7 \\
\hline
\end{tabular}

${ }^{\text {a }}$ Premix provided per kg diet: vitamin A $10000 \mathrm{IU}$; vitamin D $2000 \mathrm{IU}$; vitamin E $20 \mathrm{IU}$; vitamin $\mathrm{K} 0.5 \mathrm{mg}$; vitamin $\mathrm{B}_{12} 0.04 \mathrm{mg}$; nicotinic acid $60 \mathrm{mg}$; D-pantothenie $11 \mathrm{mg}$; pyridoxine $2.5 \mathrm{mg}$; riboflavin $4.0 \mathrm{mg}$; biotin $0.2 \mathrm{mg}$; folic acid $0.6 \mathrm{mg}$; thiamine $3 \mathrm{mg}$; choline chloride $600 \mathrm{mg}$; Cu $8 \mathrm{mg}$; Fe $80 \mathrm{mg}$; Mn $80 \mathrm{mg}$; Zn $60 \mathrm{mg}$; Se $0.2 \mathrm{mg}$; I $0.4 \mathrm{mg}$. 
and spleen were collected and weighed to calculate the relative organ weights using the following formula: relative immune organ weight $(\mathrm{g} / \mathrm{kg})=$ immune organ weight $(\mathrm{g}) /$ body weight $(\mathrm{kg})$. The whole gastrointestinal tract was rapidly removed. The jejunum and ileum were collected and were flushed with ice-cold phosphate-buffered saline. Approximately $20 \mathrm{~cm}$ of jejunal and ileal segments were opened along the longitudinal axis. The mucosa were scratched carefully using a sterile glass microscope slide, quickly frozen in liquid nitrogen, and stored at $-80^{\circ} \mathrm{C}$ until analysis.

\section{Measurements of Serum and Liver Antioxidant Indexes}

Antioxidant indexes of serum and liver, including superoxide dismutase (SOD) and glutathione peroxidase (GSH$\mathrm{Px}$ ) activities and the malondialdehyde (MDA) level, were determined using commercial kits obtained from Nanjing Jiancheng Bioengineering Institute (Nanjing, Jiangsu, China) according to the manufacturer's instructions.

The serum was diluted to the appropriate concentration after defrosting. Then, the SOD and GSH-Px activities and MDA level were measured and were expressed as $\mathrm{U} / \mathrm{mL}$ and $\mathrm{nmol} / \mathrm{mL}$ serum, respectively.

Liver tissue $(0.3 \mathrm{~g})$ was mixed $(1: 4, \mathrm{~W} / \mathrm{V})$ with cold sodium chloride solution $\left(154 \mathrm{mmol} / \mathrm{L}, 4^{\circ} \mathrm{C}\right)$ and was homogenized by using an Ultra-Turrax homogenizer (Tekmar Co., Cincinnati, OH, USA). The suspensions obtained were centrifuged at $4450 \times g$ for $15 \mathrm{~min}$ at $4^{\circ} \mathrm{C}$. The supernatant was collected and evaluated for SOD and GSH-Px activities and the MDA level. Protein concentration was determined by the Bradford method (1976). Data were normalized against the total protein concentration in each sample for inter-sample comparison.

\section{Determination of Diamine Oxidase Activity and Endotoxin Content in the Serum}

The activity of diamine oxidase in the serum was determined according to the method described by Chen et al. (2016a). The content of endotoxin in the serum was determined using Chromogenic End-point Tachchypleus Amebocyte Lysate obtained from Xiamen Limulus Reagent Biotechnology Co., Ltd. (Xiamen, China).

Mucosal Immune Parameters

Samples of ileal and jejunal mucosa $(0.3 \mathrm{~g})$ were homogenized (1:4, W/V) with cold sodium chloride solution (154 $\mathrm{mmol} / \mathrm{L}, 4^{\circ} \mathrm{C}$ ) using an Ultra-Turrax homogenizer (Tekmar
Co.). The homogenates were centrifuged at $4450 \times g$ for 15 min at $4{ }^{\circ} \mathrm{C}$, and the supernatants were collected and stored at $-28^{\circ} \mathrm{C}$ for subsequent determination. The levels of immunoglobulin $\mathrm{M}(\operatorname{IgM})$, immunoglobulin $\mathrm{G}(\operatorname{IgG})$, and secretory immunoglobulin A (SIgA) were measured using duckspecific IgG, IgM, and SIgA enzyme-linked immunosorbent assay kits (Nanjing Jiancheng Bioengineering Institute, Nanjing, Jiangsu, China). The concentrations of IgM, IgG, and SIgA in the intestinal mucosa were standardized to the concentration of protein in each sample.

\section{Quantitative Reverse-transcription PCR}

Briefly, mucosal RNA was extracted using Trizol reagent (Takara Biotechnology, Dalian, Liaoning, China), following the manufacturer's instructions. RNA integrity was verified by gel electrophoresis followed by ethidium bromide staining. Total RNA was quantified by measuring the absorbance at $260 \mathrm{~nm}$, and RNA purity was assessed by determining the ratio of absorbance at 260 and $280 \mathrm{~nm}$ using a NanoDrop ND-2000 spectrophotometer (Nano Drop Technologies, Wilmington, DE, USA). The RNA was reverse-transcribed to cDNA using a PrimeScript ${ }^{\mathrm{TM}}$ RT reagent Kit (Takara Biotechnology, Dalian, Liaoning, China). Real-time PCR was carried out with the ABI StepOnePlus ${ }^{\mathrm{TM}}$ Real-Time PCR system (Applied Biosystems, Grand Island, NY, USA) using the following thermal cycling protocol: $95^{\circ} \mathrm{C}$ for $30 \mathrm{~s}$ followed by 40 cycles of $95^{\circ} \mathrm{C}$ for $5 \mathrm{~s}, 60^{\circ} \mathrm{C}$ for $31 \mathrm{~s}$, and a final dissociation stage of $95^{\circ} \mathrm{C}$ for $15 \mathrm{~s}, 60^{\circ} \mathrm{C}$ for $1 \mathrm{~min}$, $95^{\circ} \mathrm{C}$ for $15 \mathrm{~s}$, and $60^{\circ} \mathrm{C}$ for $15 \mathrm{~s}$. $\beta$-Actin was adopted as a reference gene. The primer sequences for the target [zonula occludens-1 (ZO-1), occludin (OCLN), claudin-1 (CLDN$1)$ ] and reference genes are listed in Table 2. The $2^{-\triangle \Delta C T}$ method (Livak and Schmittgen, 2001) was used to analyze the relative expression (fold changes), calculated relative to the control group. The result of the control group was defined as 1 .

\section{Statistical Analysis}

Data were analyzed by one-way analysis of variance (ANOVA) using SPSS statistical software (Ver. 20.0 for windows; SPSS Inc., Chicago, IL, USA). The linear and quadratic effects of dietary Pal supplementation levels were determined by polynomial contrasts. Data are presented as means and their total standard errors. Significance was considered at $P<0.05$.

Table 2. Information on primers used for real-time PCR

\begin{tabular}{cclc}
\hline \hline Gene name ${ }^{\mathrm{a}}$ & \multicolumn{1}{c}{ Gene Bank ID } & \multicolumn{1}{c}{ Primer sequence $\left(5^{\prime} \rightarrow 3^{\prime}\right)$} & Length \\
\hline \multirow{2}{*}{ ZO-1 } & XM_413773.4 & $\begin{array}{l}\text { Forward: TGTAGCCACAGCAAGAGGTG } \\
\text { Reverse: CTGGAATGGCTCCTTGTGGT }\end{array}$ & 159 \\
OCLN & NW_004679913.1 & $\begin{array}{l}\text { Forward: CTCTGCTTCCTGGCCCAGTT } \\
\text { Reverse: AGACGATGGAGGCGATGAGC }\end{array}$ & 214 \\
& NW_004678814.1 & $\begin{array}{l}\text { Forward: TCCATGCATGTGCTGTTGGC } \\
\text { Reverse: CCTGCTGCAGTTGCAGTGTT }\end{array}$ & 145 \\
$\beta$ B-Actin & NM_205518.1 & $\begin{array}{l}\text { Forward: TTGGTTTGTCAGCAAGCGG } \\
\text { Reverse: CCCCCACATACTGGCACTTT }\end{array}$ & 100 \\
\hline
\end{tabular}

${ }^{\mathrm{a}} Z O-1$, zonula occludens-1; OCLN, occludin; $C L D N-1$, claudin-1. 


\section{Results}

\section{Growth Performance}

Pal supplementation (Table 3) quadratically increased ADG $(P=0.003)$ and linearly and quadratically promoted ADFI $(P<0.05)$ of ducks during the starter period, whereas it linearly decreased ADG $(P=0.042)$ of ducks during the grower period.

\section{Relative Immune Organ Weight}

As indicated in Table 4, dietary Pal supplementation had no effect on the relative weights of the thymus, spleen, and bursa of Fabricius $(P>0.05)$ at 14 and 42 days.

\section{Serum and Liver Oxidative Status}

Serum GSH-Px activity was enhanced by Pal supplementation at 14 days (linear and quadratic, $P<0.05$ ) and 42 days (linear, $P<0.001$ ). In contrast, the MDA content was quadratically reduced by Pal supplementation at 14 and 42 days $(P<0.05)$ (Table 5). As for the liver, Pal supplementation linearly $(P=0.003)$ increased SOD activity at 42 days. Meanwhile, GSH-Px activity was enhanced by Pal supplementation at 14 days (quadratic, $P=0.044$ ) and 42 days (linear and quadratic, $P<0.001$ ). However, the MDA content was quadratically $(P=0.003)$ decreased by Pal supplementation at 14 days.

\section{Diamine Oxidase Activity and Endotoxin Content in the} Serum

As indicated in Table 6, serum diamine oxidase activity was linearly and quadratically decreased $(P<0.05)$ by Pal supplementation at 42 days. Similarly, the content of endotoxin was reduced by $\mathrm{Pal}$ supplementation at 14 days (linear and quadratic, $P<0.05$ ) and 42 days (quadratic, $P=0.017$ ), respectively.

\section{Intestinal Immunoglobulin}

Supplementation of Pal linearly and quadratically enhanced IgM content at 42 days $(P<0.05)$ and IgG content at 14 and 42 days in the jejunal mucosa $(P<0.05)$ (Table 7). Meanwhile, Pal supplementation quadratically increased the IgM content of the ileal mucosa at 14 and 42 days $(P<0.05)$. $\operatorname{IgG}$ and SIgA contents of ileal mucosa were linearly and quadratically $(P<0.05)$ elevated at 42 days after Pal incorporation.

Table 3. Effect of palygorskite supplementation on the growth performance of ducks from 1 to 42 days

\begin{tabular}{|c|c|c|c|c|c|c|c|}
\hline \multirow{2}{*}{ Item $^{a}$} & \multicolumn{4}{|c|}{ Palygorskite (g/kg) } & \multirow{2}{*}{$\mathrm{SEM}^{\mathrm{b}}$} & \multicolumn{2}{|c|}{$P$} \\
\hline & 0 & 5 & 10 & 20 & & Linear & Quadratic \\
\hline \multicolumn{8}{|c|}{ ADG (g/day/duck) } \\
\hline 1-14 days & 32.67 & 35.85 & 40.10 & 34.72 & 0.82 & 0.081 & 0.003 \\
\hline 15-42 days & 84.88 & 83.68 & 82.76 & 82.37 & 0.45 & 0.042 & 0.651 \\
\hline $1-42$ days & 67.48 & 67.74 & 68.85 & 66.76 & 0.37 & 0.750 & 0.120 \\
\hline \multicolumn{8}{|c|}{ ADFI (g/day/duck) } \\
\hline 1-14 days & 39.16 & 43.91 & 47.04 & 42.76 & 0.71 & 0.002 & $<0.001$ \\
\hline $15-42$ days & 179.40 & 176.10 & 180.18 & 176.19 & 1.92 & 0.754 & 0.939 \\
\hline $1-42$ days & 132.69 & 132.04 & 135.80 & 131.72 & 1.35 & 0.948 & 0.547 \\
\hline \multicolumn{8}{|l|}{$F: G$} \\
\hline $1-14$ days & 1.20 & 1.23 & 1.18 & 1.24 & 0.02 & 0.724 & 0.789 \\
\hline 15-42 days & 2.12 & 2.11 & 2.18 & 2.14 & 0.02 & 0.481 & 0.789 \\
\hline $1-42$ days & 1.96 & 1.95 & 1.97 & 1.98 & 0.02 & 0.712 & 0.721 \\
\hline
\end{tabular}

${ }^{a}$ ADG, average daily gain; ADFI, average daily feed intake; F:G, feed/gain ratio.

${ }^{\mathrm{b}} \mathrm{SEM}$, total standard error of means.

Table 4. Effect of palygorskite supplementation on relative immune organ weight of male ducks

\begin{tabular}{|c|c|c|c|c|c|c|c|}
\hline \multirow{2}{*}{ Item } & \multicolumn{4}{|c|}{ Palygorskite (g/kg) } & \multirow{2}{*}{$\mathrm{SEM}^{\mathrm{a}}$} & \multicolumn{2}{|c|}{$P$} \\
\hline & 0 & 5 & 10 & 20 & & Linear & Quadratic \\
\hline \multicolumn{8}{|c|}{ Thymus (g/kg body weight) } \\
\hline 14 days & 4.35 & 4.10 & 3.83 & 4.23 & 0.10 & 0.464 & 0.116 \\
\hline 42 days & 3.35 & 3.41 & 2.88 & 3.24 & 0.09 & 0.284 & 0.400 \\
\hline \multicolumn{8}{|c|}{ Spleen (g/kg body weight) } \\
\hline 14 days & 0.99 & 0.87 & 0.87 & 0.94 & 0.04 & 0.885 & 0.085 \\
\hline 42 days & 0.66 & 0.63 & 0.60 & 0.60 & 0.03 & 0.445 & 0.816 \\
\hline \multicolumn{8}{|c|}{ Bursa of Fabricius ( $\mathrm{g} / \mathrm{kg}$ body weight) } \\
\hline 14 days & 1.23 & 1.26 & 1.29 & 1.31 & 0.02 & 0.117 & 0.886 \\
\hline 42 days & 0.60 & 0.78 & 0.79 & 0.69 & 0.04 & 0.480 & 0.130 \\
\hline
\end{tabular}

${ }^{\mathrm{a}} \mathrm{SEM}$, total standard error of means. 
Table 5. Effect of palygorskite supplementation on the antioxidant status in the serum and liver of male ducks

\begin{tabular}{|c|c|c|c|c|c|c|c|}
\hline \multirow{2}{*}{ Item $^{\mathrm{a}}$} & \multicolumn{4}{|c|}{ Palygorskite (g/kg) } & \multirow{2}{*}{$\mathrm{SEM}^{\mathrm{b}}$} & \multicolumn{2}{|c|}{$P$} \\
\hline & 0 & 5 & 10 & 20 & & Linear & Quadratic \\
\hline \multicolumn{8}{|l|}{ Serum } \\
\hline \multicolumn{8}{|l|}{ SOD $(\mathrm{U} / \mathrm{mL})$} \\
\hline 14 days & 30.58 & 33.06 & 31.52 & 30.77 & 0.68 & 0.880 & 0.263 \\
\hline 42 days & 26.94 & 27.23 & 27.19 & 27.70 & 0.60 & 0.697 & 0.932 \\
\hline \multicolumn{8}{|c|}{ GSH-Px (U/mL) } \\
\hline 14 days & 661.26 & 813.66 & 807.16 & 806.28 & 20.84 & 0.011 & 0.038 \\
\hline 42 days & 716.05 & 828.27 & 838.89 & 925.21 & 21.75 & $<0.001$ & 0.697 \\
\hline \multicolumn{8}{|c|}{ MDA (nmol/mL) } \\
\hline 14 days & 3.88 & 2.19 & 3.60 & 3.62 & 0.15 & 0.463 & $<0.001$ \\
\hline 42 days & 3.85 & 2.66 & 3.59 & 3.47 & 0.13 & 0.808 & 0.012 \\
\hline \multicolumn{8}{|l|}{ Liver } \\
\hline \multicolumn{8}{|c|}{ SOD (U/mg protein) } \\
\hline 14 days & 222.89 & 249.21 & 228.65 & 238.51 & 3.53 & 0.443 & 0.215 \\
\hline 42 days & 255.00 & 294.50 & 338.93 & 320.73 & 9.84 & 0.003 & 0.081 \\
\hline \multicolumn{8}{|c|}{ GSH-Px (U/mg protein) } \\
\hline 14 days & 40.16 & 41.65 & 42.20 & 39.03 & 0.57 & 0.564 & 0.044 \\
\hline 42 days & 30.71 & 35.55 & 41.17 & 36.40 & 0.84 & $<0.001$ & $<0.001$ \\
\hline \multicolumn{8}{|c|}{ MDA (nmol/mg protein) } \\
\hline 14 days & 1.15 & 1.02 & 0.98 & 1.09 & 0.02 & 0.219 & 0.003 \\
\hline 42 days & 1.14 & 1.06 & 1.06 & 1.14 & 0.03 & 0.978 & 0.188 \\
\hline
\end{tabular}

${ }^{\text {a }}$ SOD, superoxide dismutase; GSH-Px, glutathione peroxidase; MDA, malonaldehyde.

${ }^{\mathrm{b}} \mathrm{SEM}$, total standard error of means.

Table 6. Effect of palygorskite supplementation on diamine oxidase activity and endotoxin content in the serum

\begin{tabular}{|c|c|c|c|c|c|c|c|}
\hline \multirow{2}{*}{ Item } & \multicolumn{4}{|c|}{ Palygorskite (g/kg) } & \multirow{2}{*}{$\mathrm{SEM}^{\mathrm{a}}$} & \multicolumn{2}{|c|}{$P$} \\
\hline & 0 & 5 & 10 & 20 & & Linear & Quadratic \\
\hline \multicolumn{8}{|c|}{ Diamine oxidase (U/L) } \\
\hline 14 days & 13.43 & 10.02 & 10.04 & 10.56 & 0.57 & 0.084 & 0.077 \\
\hline 42 days & 13.71 & 11.38 & 10.28 & 11.59 & 0.44 & 0.045 & 0.029 \\
\hline \multicolumn{8}{|c|}{ Endotoxin $(\mathrm{EU} / \mathrm{mL})$} \\
\hline 14 days & 0.20 & 0.17 & 0.16 & 0.18 & 0.01 & 0.047 & 0.001 \\
\hline 42 days & 0.61 & 0.47 & 0.45 & 0.59 & 0.02 & 0.741 & 0.017 \\
\hline
\end{tabular}

${ }^{\mathrm{a}} \mathrm{SEM}$, total standard error of means.

\section{Intestinal Gene Expression}

As shown in Table 8, Pal supplementation quadratically $(P$ $=0.033$ ) elevated the mRNA level of $O C L N$ in the jejunal mucosa at 14 days. mRNA expression of $Z O-1$ in ileal mucosa was linearly $(P=0.027)$ increased at 42 days by $\mathrm{Pal}$ supplementation.

\section{Discussion}

The results in the present study showed that dietary Pal supplementation increased ADG and ADFI of ducks during the starter period. These results are in agreement with the findings of Zhang et al. (2017), who discovered that Pal supplementation $(5,10,15$, or $20 \mathrm{~g} / \mathrm{kg})$ improved ADG and ADFI (linear and quadratic) of broilers during the starter period. Likewise, it has been reported that dietary $1 \% \mathrm{Pal}$ supplementation improved the laying percentage and feed/ eggs produced ratio of laying hens (Chalvatzi et al., 2014). In weaned piglets, the incorporation of $2 \mathrm{~g} / \mathrm{kg} \mathrm{Pal}$ in the diet improved growth performance by reducing the feed/gain ratio, whereas $3 \mathrm{~g} / \mathrm{kg}$ Pal showed no effect (Zhang et al., 2013). In contrast, neither $2.0 \%$ natural Pal nor heat-modified Pal supplementation caused desirable effects on laying performance (Qiao et al., 2015), and 0.5 mass $\%$ or 1.0 mass $\% \mathrm{Pal}$ inclusion did not affect body mass, feed intake, and feed/gain ratio in broilers (Chen et al., 2016b). The growth performance of broilers was not significantly improved by dietary Pal supplementation in a study by Cheng et al. (2016b). These inconsistent results suggest that the effect of 
Table 7. Effect of palygorskite supplementation on immunoglobulin concentrations in intestinal mucosa of male ducks

\begin{tabular}{|c|c|c|c|c|c|c|c|}
\hline \multirow{2}{*}{ Item $^{\mathrm{a}}$} & \multicolumn{4}{|c|}{ Palygorskite (g/kg) } & \multirow{2}{*}{$\mathrm{SEM}^{\mathrm{b}}$} & \multicolumn{2}{|c|}{$P$} \\
\hline & 0 & 5 & 10 & 20 & & Linear & Quadratic \\
\hline \multicolumn{8}{|l|}{ Jejunum } \\
\hline \multicolumn{8}{|c|}{$\operatorname{IgM}(\mu \mathrm{g} / \mathrm{mg}$ protein $)$} \\
\hline 14 days & 7.71 & 7.61 & 8.12 & 7.90 & 0.08 & 0.126 & 0.692 \\
\hline 42 days & 7.19 & 7.46 & 8.77 & 7.67 & 0.18 & 0.031 & 0.019 \\
\hline \multicolumn{8}{|c|}{$\operatorname{IgG}(\mu \mathrm{g} / \mathrm{mg}$ protein $)$} \\
\hline 14 days & 9.74 & 10.37 & 13.00 & 11.22 & 0.33 & 0.002 & 0.016 \\
\hline 42 days & 10.51 & 10.54 & 15.64 & 11.51 & 0.50 & 0.003 & 0.001 \\
\hline \multicolumn{8}{|c|}{$\operatorname{SIgA}(\mu \mathrm{g} / \mathrm{mg}$ protein $)$} \\
\hline 14 days & 0.66 & 0.68 & 0.66 & 0.68 & 0.01 & 0.578 & 0.980 \\
\hline 42 days & 0.40 & 0.40 & 0.43 & 0.44 & 0.01 & 0.221 & 0.976 \\
\hline \multicolumn{8}{|l|}{ Ileum } \\
\hline \multicolumn{8}{|c|}{$\operatorname{IgM}(\mu \mathrm{g} / \mathrm{mg}$ protein $)$} \\
\hline 14 days & 7.18 & 8.65 & 8.54 & 7.66 & 0.17 & 0.259 & $<0.001$ \\
\hline 42 days & 9.06 & 11.23 & 9.85 & 9.36 & 0.29 & 0.816 & 0.016 \\
\hline \multicolumn{8}{|c|}{$\operatorname{IgG}(\mu \mathrm{g} / \mathrm{mg}$ protein $)$} \\
\hline 14 days & 12.56 & 13.18 & 13.80 & 12.82 & 0.23 & 0.487 & 0.090 \\
\hline 42 days & 14.20 & 18.39 & 20.38 & 16.83 & 0.60 & 0.013 & $<0.001$ \\
\hline \multicolumn{8}{|c|}{$\operatorname{SIgA}(\mu \mathrm{g} / \mathrm{mg}$ protein $)$} \\
\hline 14 days & 0.85 & 0.91 & 0.93 & 0.90 & 0.02 & 0.224 & 0.167 \\
\hline 42 days & 0.89 & 1.00 & 1.07 & 1.00 & 0.02 & 0.018 & 0.021 \\
\hline
\end{tabular}

${ }^{\mathrm{a}} \mathrm{IgM}$, immunoglobulin M; IgG, immunoglobulin G; SIgA, secretory immunoglobulin A.

${ }^{\mathrm{b}}$ SEM, total standard error of means.

Table 8. Effect of palygorskite supplementation on the expression of barrier function-related genes in intestinal mucosa of male ducks

\begin{tabular}{|c|c|c|c|c|c|c|c|}
\hline \multirow{2}{*}{ Item $^{a}$} & \multicolumn{4}{|c|}{ Palygorskite (g/kg) } & \multirow{2}{*}{$\mathrm{SEM}^{\mathrm{b}}$} & \multicolumn{2}{|c|}{$P$} \\
\hline & 0 & 5 & 10 & 20 & & Linear & Quadratic \\
\hline \multicolumn{8}{|l|}{ Jejunum } \\
\hline \multicolumn{8}{|l|}{$Z O-1$} \\
\hline 14 days & 1.00 & 1.05 & 1.22 & 1.07 & 0.03 & 0.124 & 0.065 \\
\hline 42 days & 1.00 & 1.02 & 0.98 & 1.13 & 0.03 & 0.240 & 0.292 \\
\hline \multicolumn{8}{|l|}{$O C L N$} \\
\hline 14 days & 1.00 & 1.24 & 1.10 & 1.04 & 0.04 & 0.943 & 0.033 \\
\hline 42 days & 1.00 & 1.07 & 1.04 & 1.09 & 0.05 & 0.673 & 0.917 \\
\hline \multicolumn{8}{|l|}{$C L D N-1$} \\
\hline 14 days & 1.00 & 1.04 & 1.08 & 1.02 & 0.02 & 0.672 & 0.324 \\
\hline 42 days & 1.00 & 0.96 & 1.05 & 1.05 & 0.02 & 0.158 & 0.545 \\
\hline \multicolumn{8}{|l|}{ Ileum } \\
\hline \multicolumn{8}{|l|}{$Z O-1$} \\
\hline 14 days & 1.00 & 1.12 & 1.28 & 1.17 & 0.04 & 0.075 & 0.162 \\
\hline 42 days & 1.00 & 1.03 & 1.19 & 1.13 & 0.03 & 0.027 & 0.347 \\
\hline \multicolumn{8}{|l|}{$O C L N$} \\
\hline 14 days & 1.00 & 0.98 & 1.02 & 1.06 & 0.05 & 0.636 & 0.781 \\
\hline 42 days & 1.00 & 1.01 & 1.07 & 1.02 & 0.04 & 0.752 & 0.771 \\
\hline \multicolumn{8}{|l|}{$C L D N-1$} \\
\hline 14 days & 1.00 & 1.05 & 1.06 & 0.99 & 0.05 & 0.980 & 0.595 \\
\hline 42 days & 1.00 & 1.13 & 1.24 & 1.16 & 0.05 & 0.167 & 0.268 \\
\hline
\end{tabular}

${ }^{\text {a }}$ ZO-1, zonula occludens-1; OCLN, occludin; $C L D N-1$, claudin-1.

${ }^{\mathrm{b}} \mathrm{SEM}$, total standard error of means. 
Pal supplementation on animal growth performance may depend on animal species, duration of supplementation, and the dosage used. There are several explanations why Pal improved animal performance: Pal might absorb adverse factors in the feed, thus reducing intestinal impairment and preventing gastrointestinal upsets (Slamova et al., 2011). By taking a Pal-containing diet, the intestinal morphology can be improved (Qiao et al., 2015; Chen et al., 2016a), and intestinal digestive enzyme activities can be enhanced (Qiao et al., 2015; Chen et al., 2016b). In addition, nutrient digestibilitypromoting (Tang et al., 2000; Lv et al., 2015; Chen et al., 2016b) and antibacterial effects (Slamova et al., 2011) are other key functions of $\mathrm{Pal}$ in animal production. These factors may together contribute to the improved performance in animal production. Moreover, we observed that Pal supplementation decreased the ADG of ducks during the grower period, which may be related to ADFI and environmental factors in this period.

The thymus and bursa of Fabricius are two organs that play vital roles in cellular and humoral immunity (Sharma, 1999). The spleen is a fascinating organ that accommodates the capture and destruction of pathogens and the induction of adaptive immune responses (Mebius and Kraal, 2005). The present study revealed that dietary Pal supplementation did not affect the relative immune-organ weights in ducks. However, dietary natural clinoptilolite (an aluminum silicate clay) and modified clinoptilolite both increased the relative weights of immune organs in broiler chickens that were repeatedly challenged with lipopolysaccharide (Wu et al., 2013). These inconsistent results may be related to the health status of the animals. In addition, animal species and the type, usage, and amount of clay used may account for these discrepancies.

SOD and GSH-Px are two main antioxidant enzymes in the body that can remove oxygen free radicals (Wills, 1966; Ermak and Davies, 2002). As the major end product of lipid peroxidation, MDA is an indicator compound, and MDA content can be used to assess the extent of lipid peroxidation (Sumida et al., 1989). In the present study, we found that dietary supplementation of Pal significantly enhanced or tended to enhance GSH-Px and SOD activities and reduced MDA accumulation in the serum and liver, indicating that Pal inclusion improves the antioxidant capacity of ducks. A similar result was reported by Chen et al. (2016a), who reported that $10 \mathrm{~g} / \mathrm{kg}$ Pal supplementation increased the intestinal T-SOD activity of broilers. In addition, the improved antioxidant capacity upon Pal supplementation in this study was in agreement with the results of Wu et al. (2013), who found that clinoptilolite supplementation increased the activities of SOD, GSH-Px, and catalase, whereas it decreased the MDA concentration in the livers of broilers. A recent study showed that Pal supplementation reduced oxidative stress in sows by lowering the levels of thiobarbituric acid reactive substances and ferric reducing ability of plasma (Papadopoulos et al., 2016). Pavelić et al. (2003) claimed that clay minerals such as zeolite (also known as silicate clay) can serve as reactive oxygen species scavengers. Simi- larly, a recent study conducted by Cervini-Silva et al. (2015) revealed that Pal dose-dependently inhibited thiobarbituric acid reactive substance generation by directly scavenging hydroxyl radicals, which was correlated with its surface sites, a signature of specific adsorption. Thus, this beneficial function of Pal would contribute to the improved oxidative status of birds receiving Pal administration.

In the present study, Pal supplementation increased IgM and $\operatorname{IgG}$ concentrations of the jejunal mucosa and $\operatorname{IgM}, \operatorname{IgG}$, and SIgA concentrations of the ileal mucosa during the experimental period. The results are in agreement with those reported by Chen et al. (2016a), who found that Pal supplementation elevated the concentrations of IgM and SIgA in the ileum in broilers. Islam et al. (2014) reported that $0.5 \%$ dietary artificial zeolite significantly increased the $\operatorname{IgG}$ concentration in both growing and finishing stages in pigs. Similar elevations of the serum $\operatorname{IgG}$ concentration have been observed in growing pigs supplemented with $0.5 \%$ and $1.0 \%$ sericite (silicate clay) ( $\mathrm{Li}$ and $\mathrm{Kim}, 2013$ ). Silicate, as a superantigen, can active polyclonal human $\mathrm{T}$ cells to improve immunity (Ueki et al., 1994). Likewise, Jung et al. (2010) found that aluminosilicate administration could increase the phagocytic activities of polymorphonuclear leucocytes, serum antibody production, and spleen B cell ratio in mice. The major chemical composition of Pal is aluminosilicate. Together, these studies suggest that the beneficial effects of Pal supplementation on immunoglobulin production may be associated with its major chemical component, aluminosilicate.

DAO is a highly active enzyme that is secreted by intestinal epithelial cells. Endotoxin is a metabolite of gramnegative bacteria and is a unique structure of their cell wall. DAO activity and endotoxin content in the blood can be used as indicators of intestinal barrier function and intestinal permeability (Luk et al., 1983; Ammori et al., 2003). Tight junction proteins, including $Z O-1, O C L N$, and claudins, are responsible for intestinal barrier function (Gu et al., 2011). Previous studies have indicated that reduced expression of ZO-1 was correlated with increased intestinal permeability (Gu et al., 2011; Song et al., 2014). In the present study, Pal supplementation significantly decreased DAO activity and the endotoxin content in the serum, but enhanced the mRNA expression of $O C L N$ in the jejunal mucosa at 14 days and that of $Z O-1$ in the ileal mucosa at 42 days. These results indicated that $\mathrm{Pal}$ supplementation had a beneficial effect on intestinal barrier function. This was in agreement with the results of Chen et al. (2016a), who found that dietary Pal supplementation improved intestinal barrier function in broilers by lowering serum DAO activity and elevating the mRNA expression of intestinal ZO-1. Zhang et al. (2013) demonstrated that Pal supplementation improved intestinal barrier function in weaned piglets via decreasing endotoxin content and DAO activity in the plasma. It has been reported that minerals in clay may act as an antisecretory agent that prevents intestinal damage (Guarino et al., 2009). Because of its large specific surface area, Pal may cover the intestinal mucosa and thus form a barrier immediately after ingestion 
(Zhang et al., 2013). Moreover, More et al. (1992) found that Pal exerts cytoprotective effects on the intestine by modifying polysaccharide components of gastrointestinal glycoproteins, which play a key role in maintaining intestinal integrity. In addition, the capacity to bind toxins (Schell et al., 1993) and improve immune function (González et al., 2004), and the anti-inflammatory function of Pal (Juárez et al., 2016; López-Pacheco et al., 2017) may contribute to the improvement in intestinal permeability and intestinal barrier function as well.

\section{Conclusions}

The present study demonstrated that dietary Pal supplementation $(5,10$, or $20 \mathrm{~g} / \mathrm{kg})$ increased ADG and ADFI in ducks during the starter period. Pal supplementation promoted the oxidative status of the ducks as evidenced by enhanced SOD and GSH-Px activities and reduced MDA contents in the serum and liver. DAO activity and endotoxin content in the serum were decreased, whereas the mRNA expression of ZO-1 and OCLN in intestinal mucosa was increased by Pal supplementation. Thus, dietary Pal supplementation can improve growth performance, antioxidant capacity, and intestinal barrier function of ducks.

\section{Acknowledgments}

The study was supported by the open funding of the Xuyi County Government (2015-01).

\section{References}

Ammori BJ, Fitzgerald P, Hawkey P and Mcmahon MJ. The early increase in intestinal permeability and systemic endotoxin exposure in patients with severe acute pancreatitis is not associated with systemic bacterial translocation: molecular investigation of microbial DNA in the blood. Pancreas, 26: 18-22. 2003.

Bampidis VA, Christodoulou V, Theophilou N and Kotsampasi V. Effect of dietary palygorskite on performance and blood parameters of lactating Holstein cows. Applied Clay Science, 91-92: 25-29. 2014.

Bradford MM. A rapid and sensitive method for the quantitation of microgram quantities of protein utilizing the principle of protein-dye binding. Analytical Biochemistry, 72: 248-254. 1976.

Cervini-Silva J, Nieto-Camacho A and Gómez-Vidales V. Oxidative stress inhibition and oxidant activity by fibrous clays. Colloids and Surfaces B: Biointerfaces, 133: 32-35. 2015.

Chalvatzi S, Arsenos G, Tserveni-Goussi A and Fortomaris P. Tolerance and efficacy study of palygorskite incorporation in the diet of laying hens. Applied Clay Science, 101: 643-647. 2014.

Chen YP, Cheng YF, Li XH, Zhang H, Yang WL, Wen C and Zhou YM. Dietary palygorskite supplementation improves immunity, oxidative status, intestinal integrity, and barrier function of broilers at early age. Animal Feed Science and Technology, 219: 200-209. 2016a.

Chen YP, Cheng YF, Yang WL, Li XH, Wen C, Wang WB, Wang AQ and Zhou YM. An evaluation of palygorskite inclusion on the growth performance and digestive function of broilers. Applied Clay Science, 129: 1-6. 2016 b.
Cheng YF, Chen YP, Li XH, Yang WL, Wen C and Zhou YM. Effects of palygorskite inclusion on the growth performance, meat quality, antioxidant ability, and mineral element content of broilers. Biological Trace Element Research, 173: 194-201. 2016.

Ermak G and Davies KJ. Calcium and oxidative stress: from cell signaling to cell death. Molecular Immunology, 38: 713-721. 2002.

Galán E. Properties and applications of palygorskite-sepiolite clays. Clay Minerals, 31: 443-454. 1996.

Ghadiri M, Chrzanowski W and Rohanizadeh R. Biomedical applications of cationic clay minerals. RSC Advances, 5: 2946729481. 2015.

González R, Sánchez de Medina F, Martínez-Augustin O, Nieto A, Gálvez J, Risco S and Zarzuelo A. Anti-inflammatory effect of diosmectite in hapten-induced colitis in the rat. British Journal of Pharmacolgy, 141: 951-960. 2004.

Gu L, Li N, Gong J, Li Q, Zhu W and Li J. Berberine ameliorates intestinal epithelial tight-junction damage and down-regulates myosin light chainkinase pathways in a mouse model of endotoxinemia. Journal of Infectious Diseases, 203: 16021612. 2011.

Guarino A, Vecchio AL and Pirozzi MR. Clinical role of diosmectite in the management of diarrhea. Expert Opinion on Drug Metabolism \& Toxicology, 5: 433-440. 2009.

Islam MM, Ahmed ST, Kim SG, Mun HS and Yang CJ. Dietary effect of artificial zeolite on performance, immunity, faecal microflora concentration and noxious gas emissions in pigs. Italian Journal of Animal Science, 3: 830-835. 2014.

Juárez E, Ronquillo de Jesús E, Nieto-Camacho A, Kaufhold S, García-Romero E, Suárez M and Cervini-Silva J. The role of sepiolite and palygorskite on the migration of leukocyte cells to an inflammation site. Applied Clay Science, 123: 315-319. 2016.

Jung BG, Toan NT, Cho SJ, Ko JH, Jung YK and Lee BJ. Dietary aluminosilicate supplement enhances immune activity in mice and reinforces clearance of porcine circovirus type 2 in experimentally infected pigs. Veterinary Microbiology, 143: 117125. 2010 .

Kotsampasi B, Bampidis VA, Christodoulou C, Theophiloud N and Christodoulou V. Effect of dietary palygorskite on performance of lactating ewes. Applied Clay Science, 143: 76-79. 2017.

Li J and Kim IH. Effects of dietary supplementation of sericite on growth performance, nutrient digestibility, blood profiles and fecal microflora shedding in growing pigs. Animal Feed Science and Technology, 184: 100-104. 2013.

Livak KJ and Schmittgen TD. Analysis of relative gene expression data using real-time quantitative PCR and the $2^{-\Delta \Delta C}$ method. Methods, 25: 402-408. 2001.

López-Pacheco CP, Nieto-Camacho A, Zarate-Reyes L, GarcíaRomero E, Suárez M, Kaufhold S, Zepeda EG and CerviniSilva J. Sepiolite and palygorskite-underpinned regulation of mRNA expression of pro-inflammatory cytokines as determined by a murine inflammation model. Applied Clay Science, 137: 43-49. 2017.

Luk GD, Bayless TM and Baylin SB. Plasma postheparin diamine oxidase. Sensitive provocative test for quantitating length of acute intestinal mucosal injury in the rat. Journal of Clinical Investigation, 71: 1308-1315. 1983.

Lv YF, Tang CH, Wang XQ, Zhao QY and Zhang JM. Effects of dietary supplementation with palygorskite on nutrient utilization in weaned piglets. Livestock Science, 174: 82-86. 2015. 
Mebius RE and Kraal G. Structure and function of the spleen. Nature Reviews Immunology, 5: 606-616. 2005.

More J, Fioramonti J and Bueno L. Changes in gastrointestinal mucins caused by attapulgite. Experimental study in rats. Gastroenterologie Clinique et Biologique, 16: 988-993. 1992.

Murray HH. Traditional and new applications for kaolin, smectite, and palygorskite: A general overview. Applied Clay Science, 17: 207-221. 2000.

Papadopoulos GA, Kanoulas V, Arsenos G, Janssens GPJ, Buyse J, Tzika ED and Fortomaris PD. Effects of palygorskite dietary supplementation on back fat mobilization, leptin levels and oxidative stress parameters in sows. Applied Clay Science, 132-133: 535-541. 2016.

Pavelić K, Katić M, Šarković N, Łerko V, Marotti T, Kralj M and Radačić M. Antioxidative and immunostimulatory effect of natural clinoptilolite in vivo. Anticancer Research, 23: 15891596. 2003.

Qiao LH, Chen YP, Wen C and Zhou YM. Effects of natural and heat modified palygorskite supplementation on the laying performance, egg quality, intestinal morphology, digestive enzyme activity and pancreatic enzyme mRNA expression of laying hens. Applied Clay Science, 104: 303-308. 2015.

Schell TC, Lindemann MD, Kornegay ET, Blodgett DJ and Doerr JA. Effectiveness of different types of clay for reducing the detrimental effects ofaflatoxin contaminated diets on performance and serum profiles of weanling pigs. Journal of Animal Science, 71: 1226-1231. 1993.

Sharma J. Introduction to poultry vaccines and immunity. Advances in Veterinary Medicine, 41: 481-494. 1999.

Slamova R, Trckova M, Vondruskova H, Zraly Z and Pavlik I. Clay minerals in animal nutrition. Applied Clay Science, 51: 395398. 2011.

Song J, Xiao K, Ke YL, Jiao JF, Hu CH, Diao QY and Zou XT. Effect of a probiotic mixture on intestinal microflora, morphology, and barrier integrity of broilers subjected to heat stress. Poultry Science, 93: 581-588. 2014.

Sumida S, Tanaka K, Kitao H and Nakadomo F. Exercise induced lipid peroxidation and leakage of enzymes before and after vitamin E supplementation. International Journal of Biochemistry, 21: 835-838. 1989.

Tang SZ, Kerry JP, Sheehan D, Buckley DJ and Morrissey PA. Dietary tea catechins and iron-induced lipid oxidation in chicken meat, liver and heart. Meat Science, 56: 285-290. 2000.

Ueki A, Yamaguchi M and Ueki H. Polyclonal human T-cell activation by silicate in vitro. Immunology, 82: 332-335. 1994.

Wills E. Mechanisms of lipid peroxide formation in animal tissues. Biochemical Journal, 99: 667-676. 1966.

Wu YN, Wu QJ, Zhou YM, Ahmad H and Wang T. Effects of clinoptilolite on growth performance and antioxidant status in broilers. Biological Trace Element Research, 155: 228-235. 2013.

$\mathrm{Xu}$ JX, Wang WB, Mu B and Wang AQ. Effects of inorganic sulfates on the microstructure and properties of ion-exchange treated palygorskite clay. Colloids and Surfaces A-Physicochemical and Engineering Aspects. 405: 59-64. 2012.

Yan R, Zhang L, Yang X, Wen C and Zhou YM. Bioavailability evaluation of zinc-bearing palygorskite as a zinc source for broiler chickens. Applied Clay Science, 119: 155-160. 2016.

Zhang JM, Lv YF, Tang CH and Wang XQ. Effects of dietary supplementation with palygorskite on intestinal integrity in weaned piglets. Applied Clay Science, 86: 185-189. 2013.

Zhang L, Yan R, Zhang RQ, Wen C and Zhou YM. Effect of different levels of palygorskite inclusion on pellet quality, growth performance and nutrient utilization in broilers. Animal Feed Science and Technology, 223: 73-81. 2017.

Zhou, $\mathrm{CH}$. An overview on strategies towards clay-based designer catalysts for green and sustainable catalysis. Applied Clay Science, 53: 97-105. 2011. 